Edward Kaniuk (Poland)

Anna Kurpiel, Editor (Poland)

Willy Brandt Centre for German and European Studies

University of Wroclaw

E-mail:anna.kurpiel@uwr.edu.pl

\title{
NATIONAL AWARENESS OF GREEK AND MACEDONIAN CHILDREN- REFUGEES FROM THE STATE EDUCATIONAL CENTER IN POLICE
}

\begin{abstract}
The paper contains excerpts of a MA thesis that was defended in 1962 in Poland. Its author was an educator and a teacher in the State Educational Center for children-refugees in a town of Police. The thesis, which includes the problem of national awareness of Greek and Macedonian children and their mutual relations, constitutes an important source for research on children-refugees from the Greek Civil War in Europe.
\end{abstract}

Key words: children-refugees, Greek Civil War, State Educational Centre, education, childhood studies, Polish People's Republic

\section{Introduction}

Presented the material is a selection from a MA thesis written at the beginning of the 1960 under the supervision of Prof. Józef Kwiatek from the Adam Mickiewicz University of Poznan, Poland.

The Author of the thesis was a young educator and - later - a teacher working in the State Education Center (SEC) for the children-refugees from the Greek Civil War. His experience is evident through about text and it is an additional value to the analyzed research material.

The described SEC was located in a small Polish town of Police in a complex of buildings adapted from a former synthetic gasoline factory. In 1951, after the summer holidays, almost all the children-refugees were moved there from the previous State Educational Center in Zgorzelec.

This is what Edward Kaniuk writes: about the SEC in Police: 
"Housing estates built by the Germans during the war, located in the middle of the forests, away from the city, were intended for the Center. 12 orphanages, each with separate management, were organized. The whole SEC was managed by the directorate, reporting directly to the Ministry of Education. A wall surrounded the Centre's area and a plaque 'Strangers are not allowed' was placed. It was like a children's town. The isolation of the SEC from the rest of the city had severe consequences for mutual relations (...)

The years 1952-1954 were the period of the greatest development of the Center in Police. The commencement of family reunification in those years [organized by the International Red Cross - AK] resulted in lively movement of the children and the youth in the Center. (...)

Documents show that in the school year 1952/53 there were 1301 pupils in the Center. In the school year 1953/54 this number rose to 1435. Three primary schools were organized. They were merged into one in 1954. From 1955, the number of children gradually decreased".

The thesis, which has not been published before, is a 68-page-long typescript. I received a copy from the Author during our meeting in Police in 2010. In the text, there are references to appendices (e.g. pupils' essays or teachers' reports). However, my version of the thesis is devoid of them.

The text is divided into an introduction, four chapters and a conclusion. The first chapter contains the history of Macedonian and Greek settlement in Poland, presentation of the research subject, methodology and literature review. The following three chapters are based on the Author's own research and include discussion on the children's national consciousness (Ch II); national awareness and the social bond within the group (Ch IIII) and their national awareness and attitudes towards Poland (Ch IV).

We can assume that Edrawd Kaniuk's MA thesis was the first analytical work on Macedonian and Greek refugees in Poland. ${ }^{1}$ It was written over ten years after the forced migration and settlement in a new country. At that time, the dreams of their imminent return to Greece had already been forgotten and the adaptation process started.

1 Besides official reports and private notes of Wacław Kopczyński, who was responsible for creating and organizing the centers on behalf of the Ministry of Education 
As pointed out by the Author, no one analyzed the critical first decade of the refugees' stay in Poland. Apart from the official documents there is no description of children-refugees between their arrival in Poland and the time when the thesis was written. That is why information about adaptation and integration of the oldest children in the group is missing. Edward Kaniuk mostly worked with children who could hardly remember or did not remember their home country and villages at all. They grew up in the reality of Polish State Educational Center.

The thesis is an original and unique document. The article words limit does not allow for including the full text. I have made an independent and subjective selection of excerpts for translation and publication. I chose the fragments which are an elaboration of Kaniuk's own research and its results. I also took into consideration the potential usefulness of the text for further research on Macedonian and Greek refugees' national identity, Greek-Macedonian mutual relations or the organization of schooling and education of children in Poland.

\section{Edward Kaniuk \\ NATIONAL AWARENESS OF GREEK AND MACEDONIAN CHILDREN- REFUGEES FROM THE STATE EDUCATIONAL CENTER IN POLICE}

\section{Police 1962 Chapter 1}

\section{(...)}

\section{Research subject}

The aim of this study is to examine the state of national consciousness and social attitudes of Greek and Macedonian children - pupils of the State Educational Center in Police. (...) The research was carried out in the school year 1959/1960, mainly in the school and orphanages. The Primary School No. 4 in Police was until 1 September 1958 a school at the State Educational Center. Greek and Macedonian children studied there. Due to the decrease in the number of children, the Center resigned from having its own school and decided to hand it over to the Education Inspector. The school became an ordinary primary school, with only some changes to the timetable resulting from additional Greek and Macedonian language classes. What was the organization of the school in the 1959/60 school year, i.e. at the time of the research? 
The school had 22 groups. 8 of which were Greek groups from Grade 1 to Grade 7 (with two parallel groups in Grade 6). There were 7 Macedonian and 7 Polish groups (Grade 1 to Grade 7). ${ }^{2}$

In total, there were 497 students in the school:

$\begin{array}{ll}\text { Macedonians } & 84 \\ \text { Greek } & 192 \\ \text { Poles } & 271\end{array}$

22 teachers worked at the school, including 3 Greek and 1 Macedonian. Two Greeks are qualified old teachers from Greece. Third one has general secondary education and the first year of the Agricultural University in Greece. Macedonian teacher has a high school diploma. These teachers were teaching Greek history and geography as well as the mother tongue.

Other subjects in Greek groups were taught by Polish teachers. Since the subject of research are Greek and Macedonian children, I will present a list that will give the most general information about them.

1. Greek children in the school year 1959/60: ${ }^{3}$

\section{Children's age}

\begin{tabular}{|l|l|l|l|l|l|l|l|l|l|l|}
\hline year of birth & 1952 & 1951 & 1950 & 1949 & 1948 & 1947 & 1946 & 1945 & 1944 & Total \\
\hline $\begin{array}{l}\text { number of } \\
\text { children }\end{array}$ & 10 & 17 & 22 & 20 & 17 & 21 & 24 & 39 & 22 & 192 \\
\hline
\end{tabular}

Gender

$\begin{array}{ll}\text { Girls } & 95 \\ \text { Boys } & 97 \\ \text { Total } & 192\end{array}$

2 At that time, the Polish educational system included a primary school of seven Grades (Grade 1 to Grade 7) and then a professional school or a four-year-high school (Grade 8 to Grade 11).

3 On the basis of school documentation used in the school chronicle / attachment number $14 /$. 
Social background

peasant 106

workers 52

intellectual 32

family condition

orphans 12

half-orphans $\quad 89$

having parents 91

place of birth

In Poland 49

In Greece $\quad 137$

Other 6

Macedonian children in the school year 1959/60:4

Children's age

\begin{tabular}{|l|l|l|l|l|l|l|l|l|l|l|}
\hline year of birth & 1952 & 1951 & 1950 & 1949 & 1948 & 1947 & 1946 & 1945 & 1944 & Total \\
\hline $\begin{array}{l}\text { number of } \\
\text { children }\end{array}$ & 2 & 3 & 7 & 10 & 12 & 17 & 16 & 10 & 7 & 84 \\
\hline
\end{tabular}

Gender

Girls 46

Boys

38

Total

84

4 On the basis of school documentation used in the school chronicle/ attachment number $14 /$. 
$\underline{\text { Social background }}$

peasant 61

workers 9

intellectual 14

family condition

orphans 7

half-orphans 24

having parents 53

place of birth

In Poland 17

In Greece $\quad 52$

Other $\quad 15$

Out of the total number of 276 Greek and Macedonian children from the Primary School No. 4 in Police, 230 live in orphanages of the State Educational Center in Police, and 46 live with their parents in the town of Police.

\section{Chapter 2}

Characteristics of the national awareness and social attitudes of children from the State Educational Center in Police in the school year 1959-60.

While discussing the symptoms of interest in the home country, one must state that they are manifested in a wide variety of forms. Systematic observation in the 1959/60 school year confirms this.

The results of the observations show, therefore, that the children are interested in their native country. What is the result of this interest, or what do the children know about Greece? I investigated this issue by analyzing children's essays and drawings (...). (...).

The theme of the essay: "What do I know about my fatherland?" 
In 112 out of 114 Greek children essays, there is a direct statement that the fatherland is Greece. In two papers, Poland is given as the homeland [children from mixed Greek-Pole marriages - ed. AK].

Out of the total of 68 essays by Macedonian children, 24 answers that their homeland is Macedonia. That is $35.3 \%$ of the total number of statements. Here are more interesting quotes: "My native country is Macedonia. Macedonia does not exist today. It is under partitions in Greece, Yugoslavia and Bulgaria. I also know that Greece has occupied the largest part of Macedonia and there are a lot of Macedonians there. Now, in Greece, they do not allow Macedonians to speak their mother tongue. Macedonians, together with Greek workers, are fighting for the independence of Macedonia and Greece. “

A 7th-grade student writes: "My homeland is / Macedonia / Greece". Here, one can see an affectionate attachment to Macedonia and then a rational reflection that Macedonia does not exist, and the student corrects to "Greece".

A student from Grade 6: "Macedonia is my fatherland. The question is about Greece, not my fatherland. I will answer the question - what do I know about Greece. “

From the essays presented above, one can see that the children's knowledge of the fatherland is incomplete and chaotic (...). However, we can assume that the children know different facts about Greece's past. They show its greatness and fame in ancient times. They mention famous people of that time. They provide a lot of facts from the period of battles with the Turks and World War II. They mention the names of the national heroes: Gotse Delchev, Dane Gruev, Yane Sandanski, Lazo Trpovski, Nikos Beloyannis, Manolis Glezos and others. (...)

The questioners also illustrate manifestations of interest in his native country and the state of the news about it. The first three questions of the 1959/60 children's survey were precisely intended to clarify these issues.

In connection with this question of the survey, it is worth showing an interesting observation, which can be summarized as follows: "most Greek children want to return to Greece, while most Macedonian children want to stay in Poland or go to another socialist country." (...).

This comparison shows that $64 \%$ of the Macedonians do not think about returning to Greece, and the corresponding percentage of Greek children is $34.6 \%$. It can be seen that Greek children are more emotionally attached to their fatherland and this is where they see their future. The fact that Macedonians dislike Greece and Greeks is well known in exile, although it is officially omitted or covered up. (...)

When discussing the state of knowledge about the native country, it is worth quoting the answers to the questionnaire: "Who is your favourite hero and why?" 
Ninety-five children, that is $60 \%^{5}$ give a character from modern Greece as their hero. In 38 responses, i.e. 21.7\%, we have a figure from Poland. 16 responses - 9.1\% - from the USSR. The remaining per cent are 22 responses that indicate a hero from other countries, and 4 answers a hero from ancient Greece.

The fact that the majority of children see their hero in a modern Greek character is an expression of the great influence of events in Greece during and after World War II.

In this group of children, the respondents indicate the figure of Manolis Glezos the most. "My favourite character is Manolis Glezos. He is the national hero of Greece. He fought for the freedom and rights of the nation. He knew the lives of the poor; therefore, he fought to improve their lives. "

The second favourite character of children is Nikos Belojanis. "My favourite hero is Nikos Belojanis because he fought for the Greek workers and peasants. However, he did not complete his intentions because he was captured and died thinking about Greece."

(...)

In order to present the issues of interest to us more fully, it is worth analyzing the factors of teaching the children, and first of all, paying attention to the results in learning the mother tongue.

The significance of the mother tongue in the conditions of children's residence in exile does not need to be justified.

When organizing a primary school for children-refugees at the SEC in Police, the need to teach the mother tongue and in the mother tongue was taken into account. (...) For several years now, the organization of the school and the number of language teaching hours is as follows:

\section{Greeks}

Grade 1 - teaching in Greek

Grade 2 - teaching in Greek plus 5 hours a week of Polish language as a subject

Grade 3 - teaching in Polish plus 6 hours a week of Greek language

Grades 4-7 - like the Grade 3.

\section{Macedonians}

Grade 1 - teaching in Macedonian

Grade 2 - teaching in Macedonian plus 5 hours a week of Polish language as a subject

5 It should be 54,6\% - AK. 

language

Grade 3 - teaching in Polish plus 8 hours a week of Macedonian

Grades 4-7 - teaching in Polish plus 6 hours a week of Macedonian language plus 2 hours a week of Greek language as a subject.

Of the total number of hours for the mother tongue, the teacher devotes a certain proportion to the history and geography of Greece.

(...)

The analysis of [pupils' grades from Greek, Macedonian and Polish language classes - AK] makes it possible to find out, at least partially, the attitude of children to the mother tongue. It is evident that the children have better grades in their mother tongue than in Polish. As it comes to Macedonian children, there is a characteristic phenomenon of overlapping the number of failures [F-grades - AK] in Polish and Greek. At the end of the school year, it turns out that these children may have better grades in Greek. Could we conclude from this that Macedonian children consider Greek a foreign language? Based on the pledge alone, such a conclusion would be too hasty. However, the materials obtained as a result of other methods allow and even dictate that this possibility should be taken into account. ${ }^{6}$ The phenomenon of receiving better grades in Greek than in Polish is also visible among Greek children.

\section{Chapter 3 \\ National awareness and the social bond within the group.}

The aim of the chapter is to show how national awareness and patriotic feelings influence the shaping of social bonds within the group. By that I mean the influence of these factors on forming the pupils' collective at school and the group of friends outside the school. (...)

How does national awareness influence the social bond within the group of surveyed children? In 1951-1958, there were only Greek and Macedonian children in the SEC and the Primary School No. 4 in Police. Gradually, this situation changed [as Polish children started to be admitted to the school - AK].

The admission of Polish children to the Center and School marked the beginning of wider social contacts between Greek and Macedonian children who until 1958 lived in an isolated environment, maintaining only occasional connections with the Polish community. (...)

I examined the relations within the group of children by analyzing the answers to the question: "Which three classmates do you like the most and why?"

6 I will return to this matter in the next chapter when discussing relations within the group of Greek and Macedonian children. 
In November 1960, I collected answers from two groups / Grade 5 and Grade 6/. I paid attention mainly to these groups because they are mixed Greek-Macedonian ones. My point was to find out what the reasons for sympathy would be.

In Grade 5 I got 10 Macedonians and 9 Greeks answers. In Grade 6: 14 answers from Macedonians and 16 from Greeks.

Among the answers in Grade 5 there are three answers from girls and seven from boys /concerns Macedonians /.

The number of votes for individual students as the most liked is as follows:

Boy / Macedonian/....... 10 votes
Boy / Macedonian /...... 8 votes
Girl/ Macedonian/........6 votes
Boy / Greek/.............. 4 votes
Girl/ Greek /.................2 votes

Toghether $\quad 30$ votes

Children give various reasons for sympathy as "friendly", "good student", "good athlete", but among 49 responses from both groups, the "nationality" of a friend was never given as the reason for sympathy. However, this is evidenced by the fact that in Grade 5 Macedonians get 14 votes from the Greeks out of 27 possible, and in Grade 6 - 17 votes out of 48 possible. Meanwhile, Greeks in these groups get a much smaller number of votes than Macedonians - in Grade 5 - 6 votes out of 30, in Grade 6 - 6 votes out of 42 .

The research materials are insufficient to make general conclusions out of them. Still, one should signal the following observation: Macedonian children in the studied groups are guided by their nationality to a greater extent when identifying the most liked colleagues than Greek students, who at least in the studied groups did not adopt such an attitude. (...)

Observation of various sports events at school provides additional material. When the Macedonian class team is playing during the handball games, Macedonians from other groups cheer them on and show great joy for their success.

Macedonian children willingly perform at school ceremonies with poems and songs in their own language. It applies primarily to celebrations on various Greek anniversaries, such as the anniversary of the liberation of Greece from Turkish rule or anniversaries of insurgent struggles.

Among older youth, the division into two national groups, shaped under national consciousness and patriotic feelings, is more clearly vis- 
ible. During the preparation of the program for the 10th anniversary of the Center in Police, in June 1961, a fight between Greek and Macedonian youth almost broke out over the dispute in which language the scene from the period of guerrilla fights in Greece should be played. The arguments of both sides were interesting. Macedonians insisted that the partisans spoke Macedonian primarily, while the Greeks insisted that the most important language was Greek. Ultimately, the teacher in charge of preparing the program had to propose a compromise way out of the problematic situation because neither side wanted to give up by threatening to give up the performances. Children played one fragment in Greek and the other in Macedonian.

Children at school widely commented on this fact. In discussions, the children used similar arguments as the participants in the dispute. One can see that the existing national division becomes more apparent whenever patriotic feelings and national pride are involved.

\section{Conclusions}

The conducted research allows for the following general conclusions:

1. National awareness and social attitude are different for children who remember their native country and different for those who left their homeland in early childhood or were born in other countries.

2. National awareness and patriotic feelings play a role in mutual relations between children, evoking increased mutual solidarity and willingness to help each other.

3. The political, social and economic conditions of life in Poland influence the habits of emigrants. Customs, the continuation of which in Polish conditions is problematic for various reasons, disappear and Polish customs' adoption occurs. It is especially evident in a case of family celebrations.

4. The dislike of the Macedonian people towards the Greeks, which has its source in the current political situation in Greece, is also reflected among the emigrants from that country in Poland. Although both sides are trying to hide this reluctance, both adults and children emigrants are basically divided into two groups: Macedonians and Greeks. This fact has severe consequences in shaping mutual relations.

5. Gradually, over time, there is an increase in interest concerning the country where the emigrants live. This growth, especially visible among children, has a serious impact on the attitude towards Poland, even leading Greek and Macedonian children to recognize it as their second homeland. 
EthnoAnthropoZoom
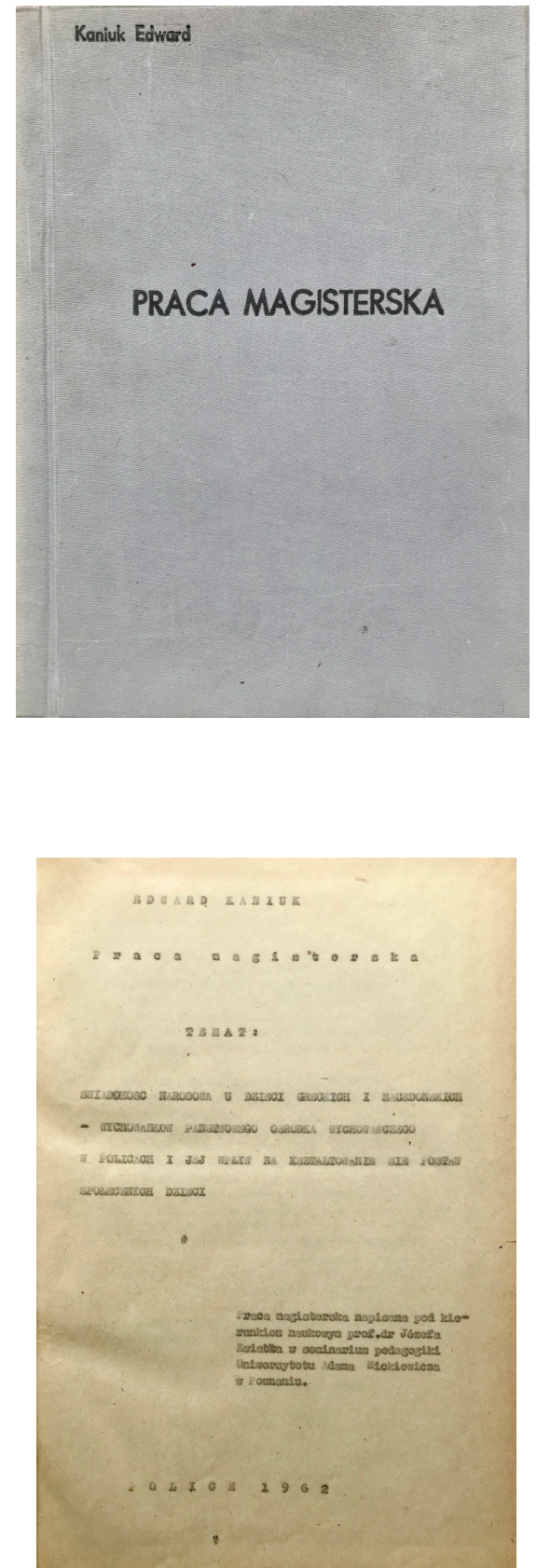

Facsimile of Edward Kanjuk's master's thesis 